13. Finlay A.Y., Anstey A.V. Dermatology inpatient care in the U.K.: rarely possible, hard to defend but occasionally essential. British Journal of Dermatology. 2019. №180(3). P.440-442. doi: 10.1111/bjd.17501.

14. Lee J.J., English J.C. 3rd. Teledermatology: A Review and Update. Am J Clin Dermatol. 2018. №19(2). P.253-260. doi: 10.1007/s40257017-0317-6.

DOI https://doi.org/10.30525/978-9934-26-075-9-51

\title{
МЕДИКО-СОЦАЛЬНІ ЧИННИКИ ТА ФІЗИЧНИЙ РОЗВИТОК ДІТЕЙ ШКІЛЬНОГО ВІКУ
}

\section{Пересипкіна Т. В.}

кандидат медичних наук, старший науковий співробітник, завідувач наукової організачї медичної допомоги школярам і підліткам ДУ «Інститут охорони здоров'я дітей та підлітків Національної академії медичних наук України»

\section{Сидоренко Т. П.}

кандидат медичних наук, старший науковий співробітник дочент кафедри гігієни та соиіальної медицини

Харківський національний університет імені В. Н. Каразіна

\section{Голубнича Г. I.}

асистент кафедри гігієни та соиіальної медиџини

Харківський начіональний університет імені В. Н. Каразіна

Зінчук А. М.

кандидат медичних наук,

старший науковий співробітник відділення наукової організаиії

медичної допомоги школярам і підліткам

ДУ «Інститут охорони здоров'я дітей та підлітків Національної

академї медичних наук України»

\section{Пересипкіна А. М.}

асистент кафедри педіатріі

Харківський наиіональний університет імені В. Н. Каразіна м. Харків, Україна

Фізичний розвиток є одним з важливих критеріїв для характеристики санітарно-епідеміологічного благополуччя населення, показником рівня 
функціональної зрілості дитячого організму. Через недовершеність процесів росту і розвитку організм дитини шкільного віку дуже чутливий до впливу змін, які відбуваються в навколишньому середовищі [1]. 3 огляду на це, своєчасне визначення чинників негативного впливу на формування параметрів фізичного розвитку стають важливою задачею профілактичної медицини.

3 метою визначення найбільш значущих медико-соціальних факторів, які асоціюються із порушеннями фізичного розвитку сучасних школярів, було розроблено анкету соціологічного дослідження, яка містила питання щодо показників фізичного розвитку (маса та зріст дитини), режиму дня (у тому числі із визначенням витрат часу на використання гаджетів, проведення вільного часу), щодо шкідливих звичок та навичок ведення здорового способу життя, фізичної активності, стосунків в родині, а також питання самооцінки власного здоров'я та свого тіла (фізичного розвитку).

Анкетуванням було охоплено 376 учнів від 10 до 17 років закладу загальної середньої освіти. Статистичну обробку проведено із використанням програм MS Office Excel, SPSS -17. 3 метою збереження особистих даних та дотриманням виявлення Гельсінської декларації анкетування було анонімним.

Аналіз гармонійності фізичного розвитку школярів було проведено на підставі співставлення даних щодо зросту та маси тіла, які були вказані школярами при проведенні анкетування із нормативними показниками (Наказ МО3 України № 802 від 13.09.2013 «Про затвердження Критеріїв оцінки фізичного розвитку дітей шкільного віку» [1].

Визначено, що у 44,4 \% учнів фізичний розвиток був гармонійний, дисгармонійний розвиток встановлено у 55,6 \% школярів. Дисгармонійний розвиток був переважно за рахунок порушень маси тіла $65,6 \%$ (дефіцит маси - 33,9 \%, надлишкова вага - 31,6 \%); порушення зросту 28,7 \% учнів (високий зріст).

Питання анкети передбачали також самооцінку власного тіла за градаціями: нормальне, худорляве, дуже худорляве, трохи худорляве, трохи повненьке, надто повненьке. Самооцінка, думка щодо власного тіла, $є$ дуже важливою у дитячому віці, коли відбуваються процеси соціалізації, формування установок на подальше життя. Дані щодо самооцінки власного тіла має місце при проведенні досліджень серед дитячого населення, зокрема у наймасштабнішому, такому як HBSC [2], яке охоплює майже всі країни Європи.

Самооцінка власного тіла школярами показала свою чутливість щодо визначення особливостей образу життя дітей.

Серед дітей, які оцінювали параметри власного тіла, як відмінні від «звичайного, нормального» рідше вказувалося на відмінний дуже добрий стан здоров'я у порівнянні із школярами, які оцінювали параметри свого 200 
тіла як «нормальні» $(33,8 \% \pm 3,9 \%$, проти 53,3\% $\% 3,9 \%, \mathrm{p}<0,001)$. Менша питома вага тих, хто веде здоровий спосіб життя $(32,5 \% \pm 3,8 \%$ проти $47,1 \% \pm 3,3 \%, \mathrm{p}<0,01)$.

Питаннями анкети, які мали максимальну кількість відмінностей були щодо родини, стосунків у ній. Так, серед дітей, які оцінювали власне тіло як відмінне від норми батьки, як «орієнтир, приклад в житті» $є$ для меншої кількості учнів $(62,5 \% \pm 4,0 \%$ проти $81,3 \% \pm 2,6 \%)$, значний відсоток вказують на незадоволеність стосунками у родині $(11,3 \% \pm 2,6 \%$ проти $1,3 \% \pm 0,8 \%)$, достовірно менше тих, хто може обговорювати будь-які питання із батьками $(63,6 \% \pm 3,9 \%$ проти $80,4 \% \pm 2,7 \%, \mathrm{p}<0,001)$; вища питома вага школярів, які вказують, що вони мало спілкуються із батьками $(8,6 \% \pm 2,3 \%$ проти $3,6 \% \pm 1,2 \%$, $\mathrm{p}<0,05)$; або не вважають за потрібно спілкуватися $(16,6 \% \pm 3,0 \%$ проти $9,3 \% \pm 1,9 \%, \mathrm{p}<0,05)$; достатня кількість учнів визначали, що має місце «напружена ситуація» в родині $(5,3 \% \pm 1,8 \%$ проти $0,9 \% \pm 0,6 \%, \mathrm{p}<0,05)$. Щодо складу родини (повна/не повна родина, тощо) відмінностей не виявлено. Оцінка умов мешкання, виявила, що серед дітей, які оцінювали власне тіло, як відмінне від норми вища питома вага тих, хто мешкав у комунальній квартирі $(9,9 \% \pm 2,4 \%$ проти $4,0 \% \pm 1,3 \%, \mathrm{p}<0,05)$. Також, серед даної групи школярів вища питома вага тих, хто не має власну кімнату $(21,9 \% \pm 3,4 \%$ проти $13,8 \% \pm 2,3 \%, p<0,05)$, і більше школярів, у чиїх родинах кількість дітей - двоє $(61,6 \% \pm 4,0 \%$ проти $45,3 \% \pm 3,3 \%, p<0,05)$.

Школярам, не в повній мірі задоволеним пропорціями власного тіла, частіше навчання здається складним $(53,0 \% \pm 4,1 \%$ проти $40,9 \% \pm$ $3,3 \%, \mathrm{p}<0,05)$. Діти, які оцінили своє тіло як відмінне від норми у меншій кількості випадків оцінюють своє знання щодо ЗСЖ як відмінне $(19,2 \% \pm 3,2 \%$ проти $36,4 \% \pm 3,2 \%, \mathrm{p}<0,001)$.

Низька самооцінка власного тіла мала відображення і у питаннях щодо режимних моментів. Так, більша питома вага таких школярів мають тривалість нічного сну менше за 6 год (15,2\% $\pm 2,9 \%$ проти $6,7 \% \pm 1,7 \%, \mathrm{p}<0,001)$. Режим харчування таких дітей у більшій кількості випадків буває «по-різному» - $(33,1 \% \pm 3,8 \%$ проти $19,6 \% \pm$ $2,7 \%$ ), перебування на свіжому повітрі становить до двох годин на день $(37,1 \% \pm 3,9 \%$ проти $26,7 \% \pm 3,0 \%, p<0,01)$.

Таким чином, визначено достовірно значущі особливості образу життя підлітків, які $є$ характерними для дітей із суб'єктивними незадовільними показниками здоров'я (низька самооцінка здоров'я), які мають соціально модельований характер. Подальшим кроком може бути ретельний аналіз визначених особливостей для запровадження відповідних профілактичних втручань. 


\title{
Література:
}

1. Наказ Міністерства охорони здоров'я України від 13.09.2013 № 802 «Критерії оцінки фізичного розвитку дітей шкільного віку». URL: https://zakon.rada.gov.ua/laws/show/z1694-13\#Text

2. International Report «Spotlight on adolescent health and well-being: Findings from the 2017/2018 Health Behavior in School-aged Children (HBSC) survey in Europe and Canada». URL: http://www.hbsc.org/ publications/international/

DOI https://doi.org/10.30525/978-9934-26-075-9-52

\section{PSYCHOPHYSIOLOGICAL DETERMINANTS OF HUMAN LONGEVITY}

\author{
Khliestova S. S. \\ Candidate of Pedagogical Sciences, \\ Associate Professor at the Department of Medical Biology \\ National Pirogov Memorial Medical University \\ Chorna V. V. \\ Candidate of Medical Sciences, \\ Associate Professor at the Department of Disaster Medicine \\ and Military Medicine \\ National Pirogov Memorial Medical University

\section{Gumeniuk N. I.} \\ Senior Lecturer at the Department of Disaster Medicine \\ and Military Medicine \\ National Pirogov Memorial Medical University \\ Sprut O. V. \\ Assistant at the Department of Medical Biology \\ National Pirogov Memorial Medical University \\ Khliestova I. V. \\ 4th-year student of Medical Faculty № 1 \\ National Pirogov Memorial Medical University \\ Vinnytsia, Ukraine
}

The problems of aging of the human body, longevity, and death in all times of the world have always worried mankind. Aging of the body is a genetically 